\title{
Forging connections, pursuing social justice: a tribute to Maarten Bavinck's conceptual and institution-building contributions to maritime studies
}

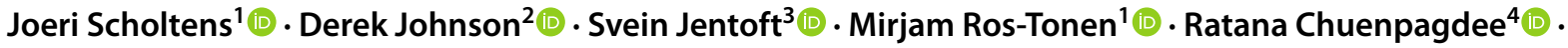

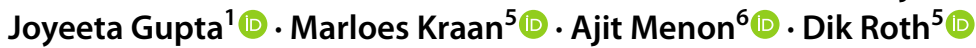

Received: 14 December 2020 / Accepted: 12 September 2021 / Published online: 30 September 2021

(c) The Author(s) 2021

\begin{abstract}
This paper is written in recognition of the contributions that Maarten Bavinck has made to the field of maritime studies and for the inspiration that he has been for many. It is hard to separate Maarten's academic and institution-building contributions from his personal qualities, particularly his interest in human relationships. Maarten's aptitude for building bridges between people, ideas, and institutions has allowed him to connect people in larger knowledge generation and action projects and forge new conceptual bridges. In addition to reflecting shortly on Maarten's key role in establishing the Centre for Maritime Research (MARE) as a institutional anchor in maritime studies, this paper reviews on some of his important and original contributions to four academic domains: legal pluralism, interactive governance, the study of fisheries conflicts, and the environment-development interface. Common threads across these domains include his long-term commitment to meticulous fieldwork in South Asia that grounds his work so firmly, his focus on achieving a more socially just use of marine and coastal resources, and his pragmatic approach that has led to original connections across distinct conceptual and institutional fields.
\end{abstract}

Keywords Maarten Bavinck $\cdot$ Legal pluralism $\cdot$ Interactive governance $\cdot$ Fisheries conflicts

\section{Introduction}

Maarten Bavinck is a maritime anthropologist, a human geographer, an international development scholar, and a community builder-all in one. We write this paper on the occasion of his retirement from the University of Amsterdam, aiming to review and reflect on his academic and

Joeri Scholtens

J.scholtens@uva.nl

Derek Johnson

Derek.Johnson@umanitoba.ca

Svein Jentoft

Svein.jentoft@uit.no

Mirjam Ros-Tonen

M.A.F.Ros-Tonen@uva.nl

Ratana Chuenpagdee

Ratanac@mun.ca

Joyeeta Gupta

J.Gupta@uva.nl

Marloes Kraan

Marloes.kraan@wur.nl institution-building contributions to the field of maritime studies. Maarten's influence on the field of maritime studies has stemmed from the empirical rigour of his research and the entrepreneurial spirit he has shown in forging connections across cultural, institutional, and disciplinary divides. His ability to recognise and seize opportunities and his trust in people have allowed him to build unlikely but productive

\author{
Ajit Menon \\ Ajit1112@gmail.com \\ Dik Roth \\ Dik.roth@wur.nl \\ 1 University of Amsterdam, Amsterdam, The Netherlands \\ 2 University of Manitoba, Winnipeg, Canada \\ 3 Arctic University of Norway, Tromso, Norway \\ 4 Memorial University, St. John, Canada \\ 5 Wageningen University and Research, Wageningen, \\ The Netherlands \\ 6 Madras Institute for Development Studies, Chennai, India
}


conceptual and institutional bridges. Maarten has also inspired many to get involved in maritime studies, including the dozens of undergraduate and graduate students he has taken to the field so as to expose them to the vagaries of fisheries.

The primary focus of Maarten's academic life has been to make sense of fisheries in South Asia, with attention particularly to the achievement of a more socially just access to resources at sea. Maarten's academic focus has been on fisheries governance and how institutions develop over time, with an abiding concern for fishers and coastal communities. This orientation has deeply influenced his perspective on other topics and sectors as well. While Maarten's academic life has been relatively short-he published his first journal article in 1996 at age 40-he has been prolific since then, and his work has had a remarkable impact. His research outputs include two monographs, six edited book volumes, eight special issues, and approximately 100 academic papers, in addition to a wealth of popular scientific contributions. However, evaluating Maarten's achievement by looking at his academic writings alone would misrepresent his contribution to maritime studies.

Maarten was one of the founders of the Centre for Maritime Research (MARE) and the driving force behind two decades of "People and the Sea" conferences that have taken place biennially in Amsterdam since 2001. These MARE conferences have become an institutional anchor for the field of maritime studies, a place where social scientists from around the world who work on the intimate relationship between people and their maritime environments feel at home. Maarten's ability to build relationships and his drive to bring people and ideas together have contributed to the success of these conferences and created a vibrant space to foster connections between maritime researchers to address academic and applied problems. MARE had matured in a fertile milieu that had established Amsterdam as a key site for maritime social studies in the preceding years. For example, in 1988, Jojada Verrips and Rob van Ginkel initiated the journal Maritime Anthropological Studies (MAST), bringing high-quality marine social science work to the University of Amsterdam. After MAST had been 'dormant' between 1993 and 2002, Maarten was one of the drivers behind the rejuvenation of the journal Maritime Studies, and has been one of the editors ever since. He thus managed to build MARE on these early foundations to eventually leave a distinct stamp on maritime studies.

Maarten's academic trajectories and achievements intimately connect to his life path and personality. Maarten's father, a Methodist missionary and human rights advocate in Sri Lanka, deeply influenced his attachment to the South Asian region. In his childhood and youth, Maarten attended school in the South Indian hill station of Kodaikanal. These early influences and experiences meant that South Asia for
Maarten is as much home as The Netherlands. Maarten's knowledge of the Tamil language from these early years and his knowledge of South Indian and Sri Lankan cultural contexts have allowed him to communicate and connect with the lives of the less privileged in Tamil Nadu and northern Sri Lanka. This personal history has provided him also with the background to build cross-cultural relations with remarkable sincerity and ease. His first book (Bavinck 1984), arising out of his Master's research, reflects this early formation and related cultural and ethical commitment to the struggle of fishers in the village of Thalayadi on Sri Lanka's northern coast. The fact that 35 years later, he continues to write about the struggles faced by fishers in Thalayadi (Bavinck 2015) and across the world (e.g. Bavinck et al. 2018) is telling of the consistency, focus, and perseverance that have underpinned his academic endeavours.

This paper reviews Maarten's academic work across four themes: legal pluralism, interactive governance, fisheries conflicts, and the environment-development interface. It subsequently draws out the connections between these areas and highlights the cross-cutting issues that mark his contributions to the field of maritime studies. While this paper is in no way an effort to exhaustively review Maarten's work or definitively summarise his research approaches, we endeavour to capture some of the major threads in his career and key contributions as a marine social scientist.

\section{Thematic reviews}

\section{Legal pluralism}

Maarten's work on fisheries and coastal communities, mainly focusing on South Asia, has contributed significantly to research on and analysis of fisheries conflicts and governance from a legal pluralism perspective. As Maarten does, we follow Vanderlinden's definition of legal pluralism as "different legal mechanisms applicable to identical situations" (1972: 20). Given how the concept is used and linked to wider theoretical perspectives on law, politics, governance, and the conflicts involved, legal pluralism has proven to be a relevant and analytically powerful conceptual lens for studying resource-related issues. In his early research on fisheries conflicts in Tamil Nadu, Maarten analysed the interactions, tensions, and conflicts in and between state agencies, the trawling sector, and artisanal fishing communities (Bavinck 1998a, b). In later work, he increasingly used a more explicitly "systemic" definition of legal pluralism (e.g. Bavinck and Gupta 2014b). Combining his growing interest in governance with this systemic focus on legal pluralism, his later work also involved a search for typologies of the interactions of legal systems. The aim was to understand what is happening in an ideal-typical manner and help 
devise solutions to address possible fishery-related conflicts (Jentoft et al. 2009; Bavinck et al. 2013a, b; Bavinck and Gupta 2014b; Gupta and Bavinck 2014). His typology inspired many $\mathrm{PhD}$ candidates to try making sense of the complexity they witnessed in the field. They used it particularly to identify the key points of convergence and conflict in multi-level governance processes in and beyond marine settings, such as water and sanitation, groundwater, drought and flood, and transboundary water.

Through his engagement with legal pluralism, Maarten has contributed substantively to the study of fisheries management and governance. Broadly construed, his work addresses the management of fisheries as a development problem, with an underlying normative commitment to mechanisms that foster collaboration and collective action. His fieldwork, especially in India, centre-staged the importance of moral principles, norms and rules in fisheries, their partially overlapping, contrasting or mutually supportive character, and the degree of their institutionalisation into discrete "systems". This mainly came down to the oftenproblematic relationship between the customary domain of fisherfolk and the formal, statutory domain represented by state authorities and agencies at multiple levels. He analysed the relationship as one of cultural distance, fear of conflict and violence, and abstention from intervention unless absolutely needed. "State law ends where fishermen law begins, and where fishermen law is effective, the state sees little reason to become involved" (Bavinck 1998b:165). These research experiences and insights paved the way for further exploration of these interactions between legal systems. In his earlier research, he explicitly linked insights from legal pluralism to commons theory. He showed that ideas about common-pool resources and common property bear a clear connection to the realm of informal law in legal pluralism (Bavinck 1998a). In his later work, he stressed how, over time, the state has become an increasingly dominant player in managing, or interfering in, fisheries by mediating or aggravating conflicts.

Another major theoretical connection that he has addressed in his more recent work is the relationship between legal pluralism and the broader theoretical domain of governance. This has enabled him to develop a fuller theoretical perspective on the often problematic interactions between legal systems. This focus on governance has been compatible with the underlying normative and developmentoriented focus of his work. This linkage between legal pluralism and interactive governance was not explicit in his first and largest work on interactive governance in fisheries (Kooiman et al. 2005) but has become prominent in more recent publications (Bavinck and Kooiman 2013; Bavinck et al. 2014a; Jentoft and Bavinck 2014).

Maarten has used his legal pluralism framework to inform his work on institutional interactions in fisheries. His findings have shown the vitality and diversity of rule-making over time, as his recent research on ring seining shows (Bavinck 2020a, b). The theoretical and analytical quality of his work is founded on his in-depth knowledge of the region and conscientious ethnographic research. Maarten's use, analysis, and expansion of legal pluralism have gone beyond assessing the details of stakeholder conflicts to also show how conflicts could be resolved politically and institutionally in governance settings.

\section{Interactive governance}

For many years, Maarten worked closely with Professor Jan Kooiman of Rotterdam's Erasmus University. Their common concern was the governance of fisheries and marine systems and the ability of these systems to address important societal issues like sustainable resource management, food security, social well-being and justice, and climate change. Maarten and Jan argued that we need to look beyond government to understand how societies or sectors like fisheries are actually governed. With the increasing complexity of modern society, civil society organisations, communities, market actors, the media, and scientific communities are also part of the governance process. Without understanding how these actors interact, it is not possible to explain why societies or sectors fail or succeed in addressing fundamental societal concerns.

The involvement of more actors may enhance participatory democracy but may also create more complex and non-linear governance processes with uncertain outcomes. Maarten and Jan suggested that research into such processes was essential not only for understanding how governance evolves but also for enhancing the governability of fisheries systems. Maarten introduced the legal pluralism perspective into Kooiman's theory (Jentoft and Bavinck 2014), thereby showing that the complexity of governance challenges is often related to multiple normative orders existing side by side. This co-existence may result in conflicts over which rules are valid in a particular governance context. Another major impact of Maarten's involvement in developing interactive governance theory was the expansion of the theory's geographical scope from its original focus on the European context.

The first result of Maarten and Jan Kooiman's collaboration was the edited volume Fish for Life: Interactive Governance for Fisheries (Kooiman et al. 2005). That book established interactive governance theory as a key point of reference in the fisheries governance field. Maarten and Jan's next product was the volume entitled Governability of Fisheries and Aquaculture: Theory and Practice (Bavinck et al. 2013a, b). In this book, they laid out the essentials of the interactive governance perspective, which they then applied to the investigation of fisheries and marine systems. 
They insisted that " $[\mathrm{t}]$ he emphasis on interactions constitutes the main innovation of this approach" and argued that "[G]overning interactions are exchanges between actors that contribute to the tackling of societal problems and opportunities" (Bavinck et al. 2013a, b:11).

Maarten also led the effort to make interactive governance more practical by publishing a handbook (Bavinck et al. 2005). The vision for this practitioner's guide grew out of a conviction that governance reform is needed to address the challenges faced by fisheries and that interactive governance offers a useful lens to help identify strengths and gaps within existing fisheries systems. This handbook guides readers through the process of applying interactive governance in fisheries contexts and is more digestible and accessible to policymakers and practitioners than Fish for Life (Kooiman et al. 2005). These contributions to interactive governance theory in fisheries can be traced back to the "Fisheries Governance and Food Security Network" (FishGovFood) that Maarten coordinated in the early 2000s. The FishGovFood network was the formal context that cemented Jan and Maarten's collaboration around interactive governance and established a broader network of scholars interested in interactive governance in fisheries that continues to be vibrantly active today in new offshoots. FishGovFood followed an interactive governance perspective in its operations and profoundly influenced its successor projects on small-scale fisheries, including the PovFish Project (Jentoft and Eide 2011) and the Too Big to Ignore (TBTI) and Dried Fish Matters partnerships.

The interactive governance perspective, the primary inspiration for PovFish and TBTI, invites careful wholesystem investigation of the nature and characteristics of all the elements, either already involved or relevant to consider, in the governance process. In this perspective, all elements of governing systems and systems to be governed have a label. When discussing institutions, interactive governance emphasises the connecting role between governance principles articulated at the "metaorder" and actions, decisions and behaviour taken at the "first-order", or daily management. Institutional arrangements are perceived to be the "second governing order". With a wealth of knowledge and on-the-ground experiences in Indian fisheries, Maarten helped ground the theory. He emphasised the importance of looking at fisheries across the entire value chain, explaining the relevance of including customary institutions in each and every node of the chain for understanding normative and interest-based conflicts. He also pointed to the sheer importance of imagination as a key ingredient in fisheries governance: "After all, the very definition of what constitutes a governance problem or opportunity depends also on the way the future is imagined" (Bavinck and Jentoft 2008: 41).

As an "open" theory, interactive governance offers scholars the possibility of investigating those aspects of fisheries governance in which they have the most interest. Maarten and his students continue to "unpack" the theory and test it empirically. At the People and the Sea conference in 2017, he organised a special session about interactive governance theory in memory of Jan Kooiman (1930-2016). In addition to reflecting on the contributions of interactive governance to social science and to fisheries and aquaculture sustainability, the session also explicitly provided a stage for scholars to discuss some of the challenges raised about the ontological underpinnings, normativity, and applicability of the theory (e.g. Song et al. 2018; Scholtens 2016). This preparedness to face and utilise criticism from students and colleagues alike also hints to Maarten's modesty and commitment to continuous theoretical improvement.

Maarten maintains an interest in the intersections of interactive governance and legal pluralism. He is particularly interested in exploring the role of institutions along the fish chain (Jentoft and Bavinck 2014). His multiple applications of interactive governance to examine social justice, poverty, and well-being concerns, as well as conflicts in fisheries and aquaculture, have helped to advance and fine-tune interactive governance thinking and continues to do so.

\section{Fisheries conflicts}

Ever since his postgraduate research, Maarten has been intrigued by and has written extensively on fisheries conflicts. In his first book (Bavinck 1984), he drew on his fieldwork carried out in the late 1970s to analyse the historical evolution of the fishing economy in a village in northern Sri Lanka. Having "been intrigued by discussions in Marxist circles" (p. xi), Maarten illustrated how adopting more capital-intensive technologies produced new rural inequalities and, consequently, conflict among fishers.

When he returned to academia a decade later, he undertook years of meticulous fieldwork to understand intersectoral fisheries conflict along the Coromandel Coast of Tamil Nadu, India, due to the mechanisation of fisheries (Bavinck 2001, 2003). He initially attributed these conflicts between the mechanised and artisanal sectors to two issues: "First, since they targeted the same species, notably shrimp, a competition for the fish resource arose .... Second, by fishing in the same waters, trawler fishermen regularly damaged artisanal fishing gear, causing substantial financial losses, as well as occasional loss of life" (2003; 635).

As he continued his fieldwork to understand the inflammatory tensions between the artisanal and mechanised sectors, he began to advance a more distinct conceptual framework grounded in legal pluralism (Bavinck 2001, 2005; Bavinck and Jyotishi 2014; Bavinck et al. 2014a). In one of his most cited papers (Bavinck 2005), Maarten put forth a theory on "fisheries conflicts in the South", in which he expressed dissatisfaction with mainstream understandings 
of conflicts which, he claimed, explained the prevalence of conflicts primarily as a matter of contrary economic interests. Maarten demonstrated, in contrast, that conflicts often emerge from the adherence of participants to different sea tenure systems (Bavinck 2005). Fishing conflicts, in other words, occur because there is a lack of consensus about norms, rules, and dispute resolution mechanisms as to who should have access to fisheries resources (Bavinck et al. 2014a).

For a proper understanding of conflict, it is necessary to specify the character of interests, and their overlaps, more precisely. Second, interests must be connected to the people and the societies of which they are part. Their pursuit is governed by rules and norms that are particular to specific social systems. Conflicts are therefore always about more than interests alone; they connect to dimensions such as law, culture, and social organisation... This is where sea tenure studies, and legal pluralism, provide a possible advance (Bavinck 2005; 806).

What Maarten understood as the social embeddedness of conflicts led him to build on the work of Rapoport (1974) to distinguish between endogenous and exogenous conflicts. Endogenous conflicts are those where the conflicting units "are part of a larger system that has its own mechanisms for maintaining a steady-state, which may include mechanisms for controlling or resolving conflict" between the respective units (Rapoport 1974: 175). Exogenous conflicts are between parties that do not belong to a larger institutional system and for which there are no joint mechanisms for control or resolution. Exogenous conflicts are challenging to resolve as it is difficult to bring the conflicting parties under one functioning governance mechanism-they pay heed to different authorities, norms, and institutions. Maarten has argued that the persistence of the fisheries conflicts between artisanal and mechanised fishers in Tamil Nadu, between fishers of Chennai and Andhra Pradesh and between fishers of India and Sri Lanka are indeed all partially attributable to their exogenous character. In his more recent work, he also demonstrates that these exogenous "conflicts are now more explosive, of longer duration, and more difficult to resolve than they were before" (Bavinck et al. 2014a:65) as a result of ocean and coastal grabs (Bavinck et al. 2017) that pit fishers against a range of new actors.

Maarten has also endeavoured to understand endogenous conflict, especially conflicts within artisanal fisheries around the use of particular gears (nets), and how traditional ur panchayats have dealt with such conflicts. His focus has been mostly on how such traditional institutions operate according to principles of fairness, whether with regard to the jurisdiction of individual fishing villages or the treatment of the aged or women-headed households (Bavinck and
Karunaharan 2006). Of particular interest to Maarten have been conflicts among competing groups of small-scale fishers, as witnessed by his work on squid-jigging in the Jaffna Region (northern Sri Lanka), where the fixed lures set out to attract squids damage the nets of other fishers active in the same area (Bavinck 2015). More recently, he has paid similar attention to conflicts among small-scale fishing groups over ring seine fishing in Tamil Nadu (Vivekanandan et al. 2019; Bavinck 2020a, b).

Maarten's transdisciplinary and entrepreneurial approach is highlighted by his work on the protracted transboundary fisheries conflict between trawler fishers from Tamil Nadu and small-scale fishers from northern Sri Lanka. Between 2010 and 2015, he led an action research project that brought together fishers, NGOs, media, political representatives, think tanks, universities, and filmmakers from both countries across national, political, and ethnic divides (Stephen et al. 2013; Scholtens and Bavinck 2018). His relentless efforts to understand and address the conflict, and commitment to an inclusive process of bottom-up governance, gave rise to both praise and resistence from an incredibly complicated arena of forces. Maarten was convinced that for a solution to this conflict to work, it had to be grounded in fishers' notions of what is just and effective. It had to give fishers a substantial say in addressing this conflict, and it had to acknowledge the historical struggles and normative convictions of all conflicting parties.

A key 2018 paper on "social struggle" (Bavinck et al. 2018) crystallises insights from his engagement with the many fisheries conflicts throughout his career. Here, Maarten takes a strong position, articulating what he called the largely ignored reality of struggle that pervades most fishers' livelihoods. He takes issue with the fact that too many researchers tend to side with the concerns of government through attention to issues like the optimal management of a fishery, rather than revealing the increasingly intense and precarious struggles to survive that much of the world's growing fisher population has to endure.

\section{The environment-development interface}

Maarten's affiliation to the International Development Studies research group at the University of Amsterdam allowed his teaching and research to pay significant attention to the environment-development interface. For Maarten, environment and development are intertwined themes that he has often analysed in tandem, focusing on the sometimes tense relationship between the two. From his first research (Bavinck and van Dijk 1980), he saw "development" as manifesting itself as the evolution of traditional fishing into a modern fisheries industry, resulting in the conflictual coexistence of both (Bavinck 2005; Bavinck and Johnson 2008; Menon et al. 2016). Maarten examines the implications of 
such tensions predominantly in terms of fisher livelihoods and well-being (Bavinck 2005; Eide et al. 2011; Bavinck et al. 2014a, b). He has argued that the development of industrial fishing (e.g. the trawler industry) leads to enclosure and degradation of fishing grounds and the consequent loss of the livelihood base of small-scale fishers (Bavinck 2011; Menon et al. 2016; Bavinck et al. 2018). He thereby defines small-scale fishers as "fishers who use beach-landing craft and passive fishing gear and have a limited range of operation" (Bavinck 2005: 806). His work, however, reveals great heterogeneity among small-scale fishers. As detailed in the previous section, this implies that conflicts not only occur between small-scale and industrialised fishers but also among small-scale fishers targeting different species and using different technologies. This again illustrates the plurality emphasised in Maarten's work-not only in terms of legal systems but also in terms of actors and conflicts (Bavinck 2005; Bavinck and Vivekanandan 2011).

Livelihood and well-being concerns also resonate in Maarten's analyses of the implications of marine protected areas (MPAs) and other conservation measures where the tense relationship between environment and development becomes manifest (Bavinck and Vivekanandan 2011; Thorpe et al. 2011). The application of the so-called BEG framework-biological-ecological [B], economic-social [E] and governance-management [G] — allowed analysing the implications of MPAs from different angles. However, Thorpe et al. (2011) made clear that scientific and policy attention to the socio-economic implications of fisher livelihoods significantly lags behind other dimensions. The livelihood implications of marine conservation, however, can be considerable. For instance, restrictions on coastal livelihoods in the Gulf of Mannar National Park and Biosphere Reserve MPA particularly affected seasonal fisher migrants, women sea-grass cutters, and harvesters of sea cucumbers (Bavinck and Vivekanandan 2011).

Regarding conservation debates, Maarten is not inclined to black-and-white descriptions of small-scale fishers as the "good guys" versus industrialised fishers as "the bad guys". Pointing at a regulation institutionalised by trawler fishers in Chennai (South India) that restricts mechanised fishing, he argues against authors like McGoodwin (1990), who deny any form of a conservation ethic among trawler fishers (Bavinck 2000). Neither is he inclined to romanticise small-scale fishers or self-governance, as shown in a study of two fisheries cooperatives in the Hambantota District in southern Sri Lanka (Amarasinghe and Bavinck 2011). Due to constraints regarding access to credit, markets, education, and health facilities, these cooperatives prioritised increasing fishing effort for fishers' welfare rather than resource conservation. Hence, the authors warn of the consequences of this choice for long-term sustainability (Amarasinghe and Bavinck 2011). Such analyses again reveal the empirical grounding of Maarten's work and his resistance to taking social categories and their characteristics for granted.

Whereas legal pluralism and interactive governance are the main analytical lenses through which Maarten analyses solutions to governing the interface between environment and development, in more recent work, he has added an inclusive development perspective as well (Bavinck et al. 2015; Ros-Tonen et al. 2015; Amarasinghe and Bavinck 2017; Gupta and Bavinck 2017). Maarten's initial deliberations on inclusiveness came in a study of regulatory activities by mechanised boat owners in Chennai that led to the exclusion of some from harbour facilities, the market, and the resource base. In that study, he argued that the inclusion of all is illusory where resources and facilities are scarce and sustainability is at stake. He argued that untrammelled inclusion would imply the collapse of the fisheries sector in the long term (Bavinck et al. 2015). This argument is reiterated in Gupta and Bavinck (2017): Maarten and his co-author make a stronger case for the need to sometimes exclude to create a scenario of coastal governance that incorporates both social and ecological concerns. Only then, the authors argue, "will coastal strategies be truly inclusive and sustainable in the long-term" (Ibid., p.36).

In summary, Maarten's work on the development-environment interface resonates with the major themes that run as a common thread through his work-legal pluralism, interactive governance, and conflict—while adding an inclusive development perspective in his later writings. The latter is also illustrative of his collegiality and proactive efforts to build conceptual bridges between his own work and the larger research group on governance and inclusive development at the University of Amsterdam that he was part of during much of his career.

\section{Discussion: forging conceptual and institutional conjunctures for social justice}

Maarten Bavinck's academic work is rooted in his strong commitment to relationships: inter-personal, intellectual, institutional, and applied. In this sense, one could position him as a quintessentially Dutch intellectual, a scholar whose personal and intellectual practice is consistent with the Dutch polder model approach to governance. In the ideal-typical view of this paradigm, collaboration and compromise among societal groups are mobilised through governance processes designed to achieve the greater good. As noted by Jan de Vries (2014), however, the "balance" of the polder model in The Netherlands required active steering and suffered significant periods of suffocating stagnation when that steering broke down or became too diffuse. Maarten's contribution lies in his polder model style of 
optimism about the capacity of human institutions to be forums for building connections, but also in the perennial governance challenge of maintaining those institutions in the face of diverse interests and social conflict. Maarten sees the world through a lens of possibility grounded in an ideal of mutual understanding while not denying the reality of forces that always test that hopefulness.

Two areas highlight the relational character of Maarten's work: Maarten as an intellectual and Maarten as a professional bridge builder. Intellectually, Maarten prefers working with middle-range theory (Merton 1967) in that he seeks to temper universalist explanations with empirical contextualisation. For Maarten, the field and inter-personal relations that he builds there are a constant check on theory. Theory is then a resource that structures interpretation but should not determine it. This middle-ground approach is highly relational as an epistemology: social analysis is always a contingent process, subject to changing conditions and further research encounters. Similarly, at the level of disciplinary commitment, Maarten has been pragmatic. While methodologically, he has a deep commitment to ethnography, as his career progressed, the influences of development studies and geography on his work became increasingly pronounced.

Maarten's theoretical choices are consistent with this relational worldview. His major theoretical commitments are to legal pluralism and interactive governance, with a more recent exploration of the idea of inclusive development. Each of these perspectives is arguably middle ground in orientation: they provide sets of guiding intellectual tools for understanding human relationships around resources, in the broad sense of the term. These analytical toolkits do not presume a shared universal reality but rather presuppose the context-specific, constructed nature of human social life. Legal pluralism, for example, is based on the assumption that the rule sets by which humans attempt to order their lives are diverse and often contradictory. That very messiness cannot but spawn variability of experience and, when it comes to the governance of resources, notions of legitimacy, rights, and claims. However, all three of these perspectives are also motivated by the possibility that relationships can be improved for mutual benefit. In legal pluralism and interactive governance, part of this is by simply recognising the legitimacy of non-government institutions and customary law.

A relational effect of Maarten's academic career has also been how his work has helped to create new kinds of intellectual conjunctures. This is evident in the fisheries field, where the bulk of his work has been conducted. Maarten has been a major player in bringing interactive governance and legal pluralism into the analysis of fisheries. But also beyond the concepts and theories that we highlighted in the first sections of this paper, he has fostered new conceptual connections, typically through collaborative work. Examples include his work in which he combined the themes of community conservation and coastal grabbing (Bavinck et al. 2017); fisheries and job satisfaction (Pollnac et al. 2012); mega-engineering and ocean fisheries (Bavinck 2011), selfgovernance, and well-being (e.g. Bavinck and Vivekanandan 2017); fisheries and poverty analysis (Bavinck 2014, 2011); coastal adaptation and inclusive development (Gupta and Bavinck 2017); legal pluralism and transition theory (Bavinck 2020a, b); marine protected areas and well-being analysis (Thorpe et al. 2011); reconciling human rights and customary law (Jentoft and Bavinck 2019); the production of coastal risk and bureaucracies (Colenbrander and Bavinck 2017); cooperatives and resilience (Amarasinghe and Bavinck 20111, 2017); and tribal conflict and land alienation (Bavinck and Jyotishi 2014).

Maarten's pragmatic approach to theory has also been challenged. Stirrat (2018), for example, charges that Maarten is insufficiently attentive to relations of power and that he overly systematises legal pluralism by using binary schemes of categorisation. Focusing on the transboundary fisheries conflict between India and Sri Lanka, Stirrat argued that seeing this conflict as one between different legal systems is "dangerously anodyne, effectively marginalising issues of power both political and economic", and provides "a thin veneer of legitimacy to claims invoking 'tradition' 'custom' and 'identity"' (ibid: 61).

Stirrat's observations have merit and connect to critiques that such a systemic approach to legal pluralism and governance would fail to adequately capture the struggles over resources in terms of the structural constraints for societal actors related to capitalism, class, or the political economy of power. However, they fall short by not positioning these characteristics of Maarten's work within his larger enterprise. Maarten's work is not power insensitive; indeed, it would be fair to characterise his primary motivation as an effort to strengthen and further the struggle for justice and progressive redistribution at sea (Bavinck et al. 2018). His proposed means, however, rest on a liberal and incrementalist notion of progress through bridge-building from within rather than an endorsement of more radical or legalistic approaches to social change. In two of his more recent articles (Bavinck et al. 2018; Bavinck and Verrips 2020), Maarten's work proposes to put conflict and struggle-including the confrontation of power differentials-at the heart of the marine social science research agenda. But instead of assuming that the powers that be are always bent on reproducing their interest at all costs, this approach would rather insist on the possibility of achieving social justice through an iterative series of compromises that allow for mutual understanding and good governance (McGoodwin 2007:592). Maarten would prefer to also acknowledge and engage histories and social realities of the "perpetrators"for example, the Indian trawlers in the case of the Palk Bay 
conflict-rather than proposing a full confrontation with their illegal practices or relying entirely on the state's legal apparatus to pursue justice.

Through his fieldwork, Maarten has tried to connect with and learn from the people he studied. His fieldwork practice emphasises the importance of experiencing the circumstances in which people live, taking sufficient time to understand what is of concern to the people he is studying, and not shying away from dirt, discomfort, or long beach walks in the burning sun for days on end, sleeping under trees or a shed if a bed is not available. To his students, he always emphasised the need to explore the thick weave of social relations defined by, and defining, people's life chances. In his classes, he consistently taught students to ground themselves empirically and open up their gaze to exploring the daily realities of living communities, rather than being preoccupied by theory in and of itself. By visiting his students in the field and doing fieldwork together, he reinforced the value of rigorous fieldwork for understanding specific circumstances and making appropriate methodological choices. Maarten's anthropological roots come through in his commitment to careful and empathetic field research.

Maarten has always aimed to be more than a distant theorist and a passive observer of the injustices around him, and the walls of academia have rarely bounded his scholarship. His ambition was, and still is, to make a difference in the lives of the poor and marginalised fisherfolk so close to his heart. He sought to root his research, often through engagement with non-academic partners, in practical governance and development problems. In doing so, Maarten often walked the tight rope between making the world of fisheries governable while not oversimplifying the complexity and chaos that characterise this industry.

His efforts have paid off in terms of his engagement with global governance forums, such as his current leadership role in the International Collective in Support of Fishworkers. Another major international institution-building achievement of Maarten's was his presidency of the International Association for Legal Pluralism from 2008 to 2015. Two recent research projects he led between 2010 and 2020 (REINCORPFISH and Fish4Food) are also examples of his collaborative and transdisciplinary approach. These two projects entailed broad-based international collaborationsthat explicitly combined intensive research with academic and non-academic partners to identify drivers of a certain problem area, with subsequent efforts to improve governance arrangements. Such interventions ranged from facilitating transboundary dialogues between conflicting Indian and Sri Lankan fishers, bringing in strategic media attention to push issues on the political agenda, to the organisation of a pilot with low-tech tools to test fish for possible chemical adulteration.
Perhaps Maarten's most important practical achievement is the success he has made out of the Centre for Maritime Research (MARE). MARE is a testament to Maarten's institution-building vision and his skill as a relationship builder. In the 20 years since 2000, Maarten has developed MARE as an organisation with a solid European base and a global reputation with flagship activities that are recognised as providing leadership in the coastal, maritime, and fisheries social science arena. The People and the Sea conference series, the journal Maritime Studies, and the MARE Publication Series have positioned MARE as a global network organisation and resulted in research projects, contributions to global policy deliberations, and support for the training of numerous postgraduate students and early-career scientists. In recent years, he has also established the Centre for Sustainable Development Studies at the University of Amsterdam in an effort to mainstream the environment-development interface throughout the university.

In sum, there is a seamless continuity between Maarten's intellectual interests and his personal relational practices. That consistency in building relations is indicative of his optimism about, and commitment to, working with others and "walking the talk". In this sense, Maarten is a social scientist par excellence: he thrives on collaborating with others, but he also has the vision and skill to translate his capacity for connecting with others to building larger institutions around the substantive areas and ethical commitments that are his passion.

\section{Declarations}

Competing interests The authors declare no competing interests.

Open Access This article is licensed under a Creative Commons Attribution 4.0 International License, which permits use, sharing, adaptation, distribution and reproduction in any medium or format, as long as you give appropriate credit to the original author(s) and the source, provide a link to the Creative Commons licence, and indicate if changes were made. The images or other third party material in this article are included in the article's Creative Commons licence, unless indicated otherwise in a credit line to the material. If material is not included in the article's Creative Commons licence and your intended use is not permitted by statutory regulation or exceeds the permitted use, you will need to obtain permission directly from the copyright holder. To view a copy of this licence, visit http://creativecommons.org/licenses/by/4.0/.

\section{References}

Amarasinghe, O., and M. Bavinck. 2011. Building resilience: fisheries cooperatives in southern Sri Lanka. In Poverty mosaics: realities and prospects in small-scale fisheries, ed. S. Jentoft, A. Eide, et al. Springer: Dordrecht. 
Amarasinghe, O., and M. Bavinck. 2017. Furthering the implementation of the small-scale fisheries guidelines: strengthening fisheries cooperatives in Sri Lanka. In the small-scale fisheries guidelines, ed. S. Jentoft, R. Chuenpagdee, and N. Franz. Springer: Dordrecht.

Bavinck, M. 1984. Small fry: The economy of petty fishermen in northern Sri Lanka. Amsterdam: Free University Press.

Bavinck, M. 1998a. One sea, three contenders: legal pluralism in the inshore fisheries of the Coromandel Coast, India. $\mathrm{PhD}$ thesis, University of Amsterdam.

Bavinck, M. 1998b. "A matter of maintaining peace" state accommodation to subordinate legal systems: The case of fisheries along the Coromandel Coast of Tamil Nadu, India. The Journal of Legal Pluralism and Unofficial Law 30 (40): 151-170.

Bavinck, M. 2000. Trawler fishers and the maintenance of social boundaries in Chennai, South India. 12. IASCP Conference, May $31^{\text {st }} 2000$.

Bavinck, M. 2001. Marine resource management: conflict and regulation in the fisheries of the Coromandel Coast. Sage Publications.

Bavinck, M. 2003. The spatially splintered state: Myths and realities in the regulation of marine fisheries in Tamil Nadu, India. Development and Change 34 (4): 633-657.

Bavinck, M. 2005. Understanding fisheries conflicts in the south - a legal pluralist perspective. Society and Natural Resources 18: 805-820.

Bavinck, M. 2011. The megaengineering of ocean fisheries: A century of expansion and rapidly closing frontiers. In Engineering Earth, 257-273. Dordrecht: Springer.

Bavinck, M. 2014. Investigating poverty through the lens of richesImmigration and segregation in Indian capture fisheries. Development Policy Review 32 (1), 33-52.

Bavinck, M. 2015. Fishing rights in post-war Sri Lanka: results of a longitudinal village enquiry in the Jaffna region. Maritime Studies 14 (1): 1 .

Bavinck, M. 2020a. The troubled ascent of a marine ring seine fishery in Tamil Nadu. Economic and Political Weekly 55 (14): 36-43.

Bavinck, M. 2020b. Implications of legal pluralism for socio-technical transition studies-scrutinizing the ascendancy of the ring seine fishery in India. The Journal of Legal Pluralism and Unofficial Law 52 (2): 134-153.

Bavinck, M., and J. Gupta. 2014a. Editorial overview: Legal pluralism, governance and aquatic resources. Current Opinion in Environmental Sustainability 11: v-vi.

Bavinck, M., and J. Gupta. 2014b. Legal pluralism in aquatic regimes: A challenge for governance. Current Opinion in Environmental Sustainability 11: 78-86.

Bavinck and Jentoft. 2008. Imagining the future. Samudra Report, No 51. Available at: https://www.icsf.net/en/samudra/article/EN/513247-Imagining-the-F.html.

Bavinck, M., and S. Jentoft. 2014. Interactive governance for sustainable fisheries: Dealing with legal pluralism. Current Opinion in Environmental Sustainability 11: 71-77.

Bavinck, M. and D. Johnson. 2008. Handling the legacy of the Blue Revolution in India-social justice and small-scale fisheries in a negative growth scenario. American Fisheries Society Symposium.

Bavinck, M., and A. Jyotishi, eds. 2014. Conflict, negotiations and natural resource management: a legal pluralism perspective from India. Routledge.

Bavinck, M., and K. Karunaharan. 2006. A history of nets and bans: restrictions on technical innovation along the Coromandel Coast of India. Maritime Studies-MAST 5 (1): 45-59.

Bavinck, M., and J. Kooiman. 2013. Applying the governability concept in fisheries - explorations from South Asia. In Governability of fisheries and aquaculture. MARE Publication Series, vol. 7, ed. M. Bavinck, R. Chuenpagdee, S. Jentoft, and J. Kooiman. Dordrecht: Springer.

Bavinck, M., and F. van Dijk. 1980. The transformation of a fishing economy: The case of Kadalur, Sri Lanka, 112. Amsterdam: Vrije Universiteit.

Bavinck, M., and J. Verrips. 2020. Manifesto for the marine social sciences. Maritime Studies 19 (2): 121-123.

Bavinck, M., and V. Vivekanandan. 2011. Conservation, conflict and the governance of fisher well-being: Analysis of the establishment of the Gulf of Mannar National Park and Biosphere Reserve. Environmental Management 47 (4): 593-602.

Bavinck, M., and V. Vivekanandan. 2017. Qualities of self-governance and wellbeing in the fishing communities of northern Tamil Nadu, India-the role of Pattinavar ur panchayats. Maritime Studies 16 (1): 1-19.

Bavinck, M., R. Chuenpagdee, M. Diallo, P. van der Heijden, J. Kooiman, R. Mahon, and S. Williams. 2005. Interactive fisheries governance. Delft: Eburon Publishers.

Bavinck, M., R. Chuenpagdee, S. Jentoft, and J. Kooiman, eds. 2013a. Governability of fisheries and aquaculture: theory and applications, vol. 7. Netherlands: Springer.

Bavinck, M., D. Johnson, O. Amarasinghe, J. Rubinoff, S. Southwold, and K.T. Thomson. 2013b. From indifference to mutual support-a comparative analysis of legal pluralism in the governing of South Asian fisheries. The European Journal of Development Research 25 (4): 621-640.

Bavinck, M., M. Sowman, and A. Menon. 2014a. Theorizing participatory governance in contexts of legal pluralism - a conceptual reconnaissance of fishing conflicts and their resolution. In Conflicts over natural resources in the global south: conceptual approaches, eds. Bavinck, M., Pellegrini, L, Mostert, E, pp. 147-165.

Bavinck, M., L. Pellegrini, and E. Mostert. 2014b. Conflicts over natural resources in the Global South: conceptual approaches.

Bavinck, M., S. Karuppiah, and S. Jentoft. 2015. Contesting inclusiveness: The anxieties of mechanised fishers over social boundaries in Chennai, South India. European Journal of Development Research 27 (4): 589-605.

Bavinck, M., F. Berkes, A. Charles, A.C.E. Dias, N. Doubleday, P. Nayak, and M. Sowman. 2017. The impact of coastal grabbing on community conservation-a global reconnaissance. Maritime Studies 16 (1): 8.

Bavinck, M., S. Jentoft, and J. Scholtens. 2018. Fisheries as social struggle: A reinvigorated social science research agenda. Marine Policy 94: 46-52.

Colenbrander, D., Bavinck, M. 2017. Exploring the role of bureaucracy in the production of coastal risks, City of Cape Town, South Africa. Ocean \& coastal management 150: 5-50.

De Vries, J. 2014. The Netherlands and the polder model: questioning the polder model concept. BMGN Low Countries Historical Review 129(1): 99. https://doi.org/10.18352/bmgn-lchr.9449.

Eide, A., M. Bavinck, and J. Raakjær. 2011. Avoiding poverty: distributing wealth in fisheries. In Poverty mosaics: realities and prospects in small-scale fisheries, ed. Eide, et al. Dordrecht: Springer.

Gupta, J., and M. Bavinck. 2014. Towards an elaborated theory of legal pluralism and aquatic resources. Current Opinion in Environmental Sustainability 11: 86-93.

Gupta, J., and M. Bavinck. 2017. Inclusive development and coastal adaptiveness. Ocean and Coastal Management 136: 29-37.

Jentoft, S. 2014. Walking the talk: Implementing the international voluntary guidelines for securing sustainable small-scale fisheries. Maritime Studies 13 (1): 16.

Jentoft, S., and M. Bavinck. 2014. Interactive governance for sustainable fisheries: Dealing with legal pluralism. Current Opinion in Environmental Sustainability 11: 71-77. 
Jentoft, S., and M. Bavinck. 2019. Reconciling human rights and customary law: Legal pluralism in the governance of small-scale fisheries. The Journal of Legal Pluralism and Unofficial Law 51 (3): 271-291.

Jentoft, S., and A. Eide, eds. 2011. Poverty mosaics: realities and prospects in small-scale fisheries. Springer Science \& Business Media.

Jentoft, S., M. Bavinck, D.S. Johnson, and K.T. Thomson. 2009. Fisheries co-management and legal pluralism: How an analytical problem becomes an institutional one. Human Organization 68 (1): 27.

Kooiman, J., S. Jentoft, M. Bavinck, and R. Pullin, eds. 2005. Fish for life, 432. Amsterdam : Amsterdam University Press.

McGoodwin, J.R. 1990. Crisis in the world's fisheries. People, problems, and policies. Stanford: Stanford University Press.

McGoodwin, J.R. 2007. Book review: Fish for life: interactive governance for fisheries. Kooiman J, Bavinck M, Jentoft S, Pullin R (Eds.), Amsterdam University Press, Amsterdam (2005). Ocean \& Coastal Management 50 (7): 590-596.

Menon, A., M. Bavinck, J. Stephen, and R. Manimohan. 2016. The political ecology of Palk Bay fisheries: Geographies of capital, fisher conflict, ethnicity and nation-state. Antipode 48: 393-411.

Merton, R.K. 1967. On theoretical sociology: five essays, old and new. New York: The Free Press (171 pp).

Pascual-Fernández, J.J., C. Pita, and M. Bavinck, eds. 2020. Smallscale fisheries in Europe: status, resilience and governance. MARE publication series, vol. 23. Springer International Publishing.

Pollnac, R., Bavinck, M., and Monnereau, I. 2012. Job satisfaction in fisheries compared. Social indicators research 109 (1): 119-133.

Rapoport, A. 1974. Conflict in man-made environment. Harmondsworth: Penguin Books.

Ros-Tonen, M., N. Pouw, and M. Bavinck. 2015. Governing beyond cities: the urban-rural interface. In Geographies of urban governance: advanced theories, methods and practices, 85-105. Cham: Springer.

Scholtens, J. 2016. Fishing in the margins: North Sri Lankan fishers' struggle for access in transboundary waters. PhD Thesis University of Amsterdam.
Scholtens, J., and M. Bavinck. 2018. Transforming conflicts from the bottom-up? Reflections on civil society efforts to empower marginalized fishers in postwar Sri Lanka. Ecology and Society 23 (3): 1.

Song, A.M., J.P. Johnsen, and T.H. Morrison. 2018. Reconstructing governability: How fisheries are made governable. Fish and Fisheries 19 (2): 377-389.

Stephen, J., A. Menon, J. Scholtens, and M. Bavinck. 2013. Transboundary dialogues and the 'politics of scale' in Palk Bay fisheries: Brothers at sea? South Asia Research 33 (2): 141-161.

Stirrat, R.L. 2018. The Palk Bay fishing dispute revisited. India Quarterly 74 (1): 61-72.

Thorpe, A., M. Bavinck, and S. Coulthard. 2011. Tracking the debate around marine protected areas: Key issues and the BEG framework. Environmental Management 47 (4): 546-563.

Vanderlinden, J. 1972. Le pluralisme juridique: essai de synthèse. In Le pluralisme juridique, ed. J. Gilissen, 19-36. Brussels: Editions de l'Université de Bruxelles.

Vivekanandan, V., M. Bavinck, and S. Sajith. 2019. Good practices of civil society organizations in supporting small-scale fisheries in Southeast India1. In Securing sustainable small-scale fisheries: Sharing good practices from around the world, ed. L. Westlund and J. Zelasney, 149-177. Rome: Food and Agricultural Organization.

Wickramasinghe, W.A.R., and M. Bavinck. 2015. Institutional landscapes affecting small-scale fishing in southern Sri Lanka - legal pluralism and its socio-economic effects. Maritime Studies 14 (1): 18.

Publisher's Note Springer Nature remains neutral with regard to jurisdictional claims in published maps and institutional affiliations. 